Humanist Studies \& the Digital Age, 6.1 (2019)

ISSN: 2158-3846 (online)

http://journals. oregondigital.org/hsda/

DOI: $10.5399 /$ uo/hsda.6.1.5

(cc) BY-ND

\title{
The Dialogues Bioregional Project: Landscape Ecology in Central Italy from the Sixth Century to the Present
}

\section{Damiano Benvegnù}

\begin{abstract}
Pope Gregory I (r. 590-604), commonly known as Saint Gregory the Great, is celebrated for re-organizing both the institutional and liturgical life of the Roman Catholic Church; for instigating the first recorded large-scale mission from Rome to England; and for his writings. Among these, a distinct importance has been attributed to his "Dialogues," a collection of four books of miracles, signs, wonders, and healings carried out by then little-known holy men, which represent a portion of central Italy as a sacred space where the Christian God is present in both human and non-human form, while also interacting with the environment by performing landscaping functions.

This article outlines the "Dialogues Bioregional Project," a digital, interdisciplinary interface on Italian landscape ecology which would promote dialogues between scientists and humanists as well as provide a modeling tool for environmental and cultural awareness. Shaped around the "Dialogues" of Pope Gregory I, this digital humanities project explores continuities and discontinuities between the socio-political and ecological history of a specific section of Italian territory, a set of multidisciplinary environmental narratives (from c. $600 \mathrm{AD}$ to the present), and local communities. My aim is to introduce readers to the ecological potentials of Gregory's book and thus prompt scholars interested in the environmental humanities and the integration of biophysical and analytical approaches with humanistic and holistic perspectives to become part of the "Dialogues Bioregional Project" and collaborate in its further development.
\end{abstract}

In his 2000 paper entitled "The Landscape Narrates" ["Il paesaggio racconta;" now collected in Turri 2010], Italian geographer Eugenio Turri argues that a landscape is first and foremost a "depository of stories" (161). These stories are told in two ways. On the one hand, there are the superficial events that represent the synchronic interactions between a human community and a specific environment. On the other hand, there are the ecological sedimentations of a territory, the diachronic stratigraphy of those events that, as inevitably as for a chemical process, have precipitated below the surface (161). Turri claims that the two sets of stories are strongly intertwined and advocates for a practice which allows for a simultaneous dual-reading: only a strong hermeneutical appreciation for this double set of narratives would in fact allow us to preserve a landscape's continuity and future. Turri's reflection is prompted by what he calls "the submersion of the pre-existing landscape," a 
process that he claims has been happening in Italy with the increasing modernization of the country. Indeed, in the last 50 years, large portions of Italy's traditionally agro-pastoral landscape have been submerged, flooded not with water but with new economic activities and industrial constructions that have erased those signs which bear witness to the historical interdependence of human communities and specific physical environments (178). Against this tendency - which he labels "riempimento" (filling) - Turri suggests paying attention to the original motivations behind the organization of a specific landscape, for two main reasons, both connected to what he sees as good eco-cultural planning. First, a better archeological knowledge would help us understand, in our current hybrid landscapes, what is "functional" and what is instead "memorial," namely the different kinds of relationships local communities have with places, spaces, and monuments that constitute their specific territories. Second, this knowledge would increase our awareness of how those landscapes which form the foundation of local identities not only can be reconstructed through the surviving evidence, but also - to be preserved - they "must be sacralized, in cultural sense" ["vanno sacralizzati (in senso culturale);" 184].

In Italy, few institutions have understood the socio-cultural relevance of such landscape planning better than the Roman Catholic Church. Although "the Christian sacralization of space was not as old as Christianity itself" (Caseau 1999,40), following its transition from minority cult practiced in private homes to imperial religion, the Church increasingly worked to transform the numerous pagan spaces scattered throughout the Italian territory into properly Christian spaces, often sacralizing for the first time or resacralizing as Christian locations that have been abandoned or forgotten. For instance, in recent years, archeology has given us early evidence of a slow "destructuring" of a pagan landscape followed by the creation of "a new, Christianized panorama," often adhering closely to the main routes connecting Rome to the adjacent provinces (Spera 2003, 39). These changes to the landscape, and the archeological/textual artifacts which document them, offer us an opportunity to follow Turri's advice to protect Italy's landscape from further eco-cultural catastrophe and submersion: by exploring the narratives behind Italy's landscape organization, we can achieve a better understanding of the alleged original interaction between humans and a specific environment. Although contemporary geographers such as Yi-Fu Tuan acknowledge that the adjective "sacred" can be applied to modern landscapes only by stretching its original meaning, these sacred narratives can nonetheless reactivate those polarized tensions as between the numinous and the quotidian, the supernatural and the scientific, that bond together human and nonhuman actants in a specific territory (Tuan, 97-99).

This article focuses on a digital project shaped around one of the most intriguing documents of the early Church, the Dialogues of Pope Gregory the Great. A collection of four books of miracles, signs, wonders, and healings carried out by then little-known holy men in sixth-century Italy, the Dialogues represented a portion of central Italy as a sacred space where the Christian God is present in both human and nonhuman form, while also interacting materially with the environment by performing landscaping functions. The stories collected in Gregory's work testify to Turri's concern for the importance of the myths connected to the original organization of a landscape as well as to what Iovino and Oppermann has called "material narrativity," namely a shared creativity in which "human and non-human players produce narrative emergences that amplify reality, also affecting our cognitive response to this reality" (8). Moreover, they can be read as excellent examples of bioregional literature: in narrating the original interaction between human and nonhuman actants within a series 
of landscapes that are now often neglected, they helped "people reimagine the places where they live and their relations with those places, as well as reflect the unique bioregional character of specific communities" (Lynch, Glotfelty \& Armbruster 2012, 4). The goal of this article is thus twofold: 1) to introduce readers to the ecological potentials of Gregory's book through an analysis of the functions performed by nonhuman agents in shaping the sacred landscapes narrated in the miracle stories; and 2) to present the Dialogues Bioregional Project (hereafter DBP), a digital humanities project that I am developing around the Dialogues, meant to create a set of near-continuous ecological narratives of central Italy from ca. $600 \mathrm{AD}$ to the present, primarily in the form a deep (or "thick") map. Accordingly, while the first section of this article is meant to display the ecological potential of Gregory's text and its crucial value as a quasi literal pre-text for an exploration of Central Italy's landscape ecology, the second and third sections focus instead on outlining theoretical premises, structure, goals, and current state of the DBP. Although a 2017 grant awarded by the Nenkom Institute for Computational Science at Dartmouth College allowed me to start working on this digital project, the DBP is still in its very early stages: not public yet, it exists as an embryonic frame only within the private repository of Dartmouth Digital Commons. The DBP's aims as described in this article are thus subject to change as the project goes public and we begin to gather data and feedback from its various users. Deep maps as the DBP aspires to be are in fact voluminous, polyvocal, and open-ended; they are enterprises meant "to provide a conceptual base for examining the nuanced and qualitative aspects of community knowledge and broadening the participatory mapping process" (Harris, 323). Consequently, it is highly likely that even my initial conception of the DBP - as a platform where scholars interested in the integration of biophysical and analytical approaches to the environment with humanistic and holistic perspectives can collaborate - will be modified by the encounters with both the local communities inhabiting the locations mentioned in Gregory's text and potential non-local users interested in the project. Yet, as provisional and aspirational as it might seem, my hope is that introducing the Dialogues as a blueprint for the landscape ecology of central Italy will indeed prompt interested scholars and communities to join the DBP and collaborate in its further development and objectives. Ultimately, I believe that by exploring the diverse ecological narratives that shape our understanding of specific physical environments, we might indeed achieve both a richer, more democratic, and more responsible sense of the fundamental connectivity of "various knowledge orders" and life-forms (Springett, 623). As a deep map, the DBP thus has "the potential to be inclusive of ecological as well as social concerns and work toward creating conversations that change the way people perceive, think about and ultimately engage with place" without neglecting the socio-economic and cultural needs of indigenous communities (633).

Finally, throughout this article I will be using terms and categories such as "space," "territory," "environment," and "landscape:" while in general discourses they might at times indicate similar entities, they nonetheless have different meanings and thus deserve a brief explanation. For "space" and the often-associated term "place," I follow Yi-Fu Tuan's 1977 canonical work, according to which while the former is abstract, objective, and geometrical, the latter is instead phenomenological, subjective, and experiential (5). In a sense, the whole DBP is an attempt to reframe what is mere representational space into a set of polysemic, multi-layered places. "Territory" has more a political tone, meaning a geographic area under the jurisdiction of a governmental authority or an administrative subdivision of a country. In this article is often used in relations to Pope Gregory's 
administration of the Italian land. The term "environment" designates instead the complex of physical, chemical, and biotic factors (such as climate, soil, and living things) that act upon an organism or an ecological community and ultimately determine its form and survival. The DBP is an environmental project in so far as it relates to the natural world, the impact of human activity on its condition, and how human cultures describe this impact both synchronically and diachronically. Lastly, as it will be better articulated later, the category of "landscape" is used in this article not as a synonym for "natural scenery" but to address the complex and performative interactions of human and nonhuman agents within a specific portion of the Earth's surface. From the perspective of landscape ecologies, the DBP thus studies and visualize the interplay of socio-cultural and environmental pattern and structure capable of affecting ecological communities across dynamic temporal and spatial scales.

\section{Gregory's Dialogues}

Pope Gregory I, commonly known as Saint Gregory the Great, was the first monk to be elected pope of the Catholic Church, an office he held from 590 AD to his death fourteen years later. Gregory is famous for re-organizing both the institutional and liturgical life of the Church; for instigating the first recorded large-scale mission from Rome to convert the Anglo-Saxon people of England to Christianity; and for his writings (including sermons, manuals, commentaries, and 850 surviving letters), which were more prolific than those of any of his predecessors as pope.

Among these writings, a distinct importance has been attributed to the Dialogues, a collection of four books of miracles, signs, wonders, and healings carried out by then little-known holy men, primarily monks, of sixth-century Italy. As the title of the work conveys, these miracles are told as a series of short narratives framed within a dialogue between Gregory himself and a deacon named Peter. While the stories are told by the former, it is the latter who triggers the narration with his relentless questioning about those Italian "virtuous men" who, to his knowledge, have nonetheless performed "no signs or miracles" (Gregory 2016, 5). Gregory proceeds to correct his deacon's opinion and narrates circa 200 of these signs or miracles, often moving from one holy man to another, but sometimes focusing at length on one individual, as in Book 2, completely devoted to the life and miracles of St. Benedict of Nursia. Several narratives in the Dialogues come (with only minor changes) from a Mediterranean "common fund of stories and teaching, upon which Eastern and Western Christian writers alike could draw" (Petersen, xxi). Yet, a significant amount of them have been probably collected through epistolary exchanges, with Gregory urging his numerous correspondents to send him via letter "the miracles of the Fathers, which we have heard took place in Italy," as he writes to Maximian, bishop of Syracuse, in July 593 (Gregory 2004, 268-269 [3.50]).1 As Carole Straw has pointed out, Gregory probably began writing the Dialogues in the summer of 593 and finished by 594, "but his work is the fruit of decades spent hearing and collecting stories of the holy men" (67). The writings thus exhibit a knowledge of the material territory where they take place which, as I will explain shortly, is functional to their overall objective.

Traditionally, the Dialogues have been read either because they contain the first biography of the founder of Western monasticism (Benedict, in Book 2) or for the theological explanations on afterlife

1 On the issue of Gregory's extradiegetic sources and intradiegetic informants, see Petersen 1984 and Laghezza 2009 , respectively. 
included in Book 4. Both historians and theologians have in fact usually ignored the rest of the Dialogues, some of them even contesting the attribution of the four books to Gregory due to the alleged lack of sophistication of the Latin writing and the low social and intellectual status of the main characters. 2 Yet, textual evidence suggests that the four books were instead very dear to Gregory, actually speaking to his concerns on both pastoral and administrative levels as they depict a portion of central Italy at a turning point in both Italic and European history. Having been both defensively and administratively abandoned by weakened Roman imperial powers based in Ravenna, central Italy was increasingly devastated by the frequent incursions of non-Italic invaders, most notably the Lombards, resulting in panic, chaos, and despair. Although scholars have disagreed on the reasons behind Gregory's geographical choices and have even accused him of historical inaccuracy, 3 we can surely say that the circa 200 miracles narrated in the Dialogues represented a portion of central Italy as a sacred space populated by holy men — and not one abandoned by God as distraught contemporaries were inclined to believe. As Laghezza has pointed out, the Dialogues can instead be considered the expression of a political and pastoral project meant to create a "privileged space - Rome and Central Italy - in which the presence of the divine was persisted and perceived, a shield against the dangers of history" (Laghezza 2012, 259).

Different categorizations of the miracle stories are possible. In her comprehensive volume on Gregory, Boesch Gajano provides a classification of the miracles but also acknowledges the difficulty implicit in any categorizations (236). Yet, even when the landscape is not the direct focus of the hagiographic narrative, each story includes elements that offer an ecological map of human and nonhuman dwelling interactions in the sixth century, and binds the landscape - in all its familiarity, generosity, and treachery - with human action and salvation. Although the book clearly belongs to a hagiographical genre quite typical in late antiquity, all the stories in the Dialogues reveal the Christian God's presence in those human-nonhuman interactions capable of performing landscaping functions. 4 The Dialogues thereby establish a "sacred geography" (Boesch Gajano 2012) in which both human communities and the whole biosphere surrounding them are mutually transformed.

As Laghezza has indicated, rural and urban realities are almost equally present in the Dialogues, but Gregory does not always offer precise geographical information about the place in which a miracle or a wonder has occurred (Laghezza 2012, 251). Despite this "terminological imprecision, variety and ostensible disorganization of territorial references" (Boesch Gajano 2004, 292), circa thirty different towns are mentioned, mostly located in the regions surrounding Rome, unsurprisingly the city that is cited the most in the four books. The Dialogues also mention urban centers that are both in northern and southern Italy, as well as a few places outside the Italic peninsula, but it is the territory that goes roughly from Ravenna to Nola that provides the location for the vast majority of the narratives. Moreover, the Dialogues show a peculiar ability to observe and narrate environmental realities that,

2 On this topic, see Clark 1986; Clark 2003; and, for an opposite perspective, Boesch Gajano 2004. Accepting Gregory's authorship, did not necessarily mean sympathy toward the Dialogues either: see for example the harsh hostility toward this book expressed by Edward Gibbon in his notorious The History of the Decline and Fall of the Roman Empire (103).

3 For two opposite perspectives on Gregory's geography in the Dialogues, see respectively Boesch Gajano 2004, 164-168; and Cremascoli 2001, 259.

4 This is not, of course, a theological argument meant to explain the connection between the divine and the natural either in general or in Gregory's theology; for such a debate with specific reference to the Dialogues, see McCready 1989, 206-

240. 
although forming only part of a larger eschatological plan, nonetheless reveal the writer's interest in the material and historical interactions between human communities and the physical world. For instance, Grégoire has noted how the sea and the land are the objects of both Gregory's essential curiosity and analytic interpretation: his ability to describe in detail distinct weather conditions speaks to a population engaged in activities that are very much influenced by and connected to what we may now perceive as minimal changes in their environment (75). The Dialogues' miraculous narratives are meant to create a peculiar space, capable of transforming, sacralizing it, a whole territory: an activity that scholars compare to the material transformation of the rural landscape produced by contemporary monks around their monastery (Boesch Gajano 2004, 295). Consequently, the landscape in Gregory's book is often characterized by a movement toward precision and particularity (for example, from the general province to a specific cave or boulder), and, even though it is always functional to a specific holy man's story, it is never mere background but a constitutive element of the miracle. Boesch Gajano claims that in the Dialogues "space shapes sanctity and it is reshaped by sanctity" (297), thus emphasizing the dynamic, almost circular and performative, nature of the landscape instead of its traditional, static and passive, visuality. In this sense, Gregory's book offers a unique opportunity to consider in a pre-modern context a notion of the landscape as a performative space which emphasizes simultaneous human intervention in and witness to landscape as the basis for ecological sustainability and cultural growth.

Yet, although all the miracles belong to such sacred geography, nonhuman elements are not explicit features of every story, and in fact, nonhuman elements perform a crucial role in less than half of stories. As we will see better shortly, only in circa seventy of the more or less 200 miracles collected in the Dialogues there is either a zoological, botanical, hydrological, or geological feature clearly implicated in the landscape building process. Nonetheless, when inserted in the right digital frame, these seventy stories equip us with a foundation for the study of the landscape ecology of central Italy, that is to say they bring forth, through their narratives, a set of patterns and structures across dynamic temporal and spatial scales in which not only biotic and abiotic processes and disturbances occur within the environment, but also testify to landscape changes capable of affecting the overall structure of ecological communities.5

\section{The Dialogues Bioregional Project}

The DBP is a digital, cross-disciplinary, and multimedia interface on Italian landscape ecology shaped around the Dialogues of Pope Gregory I. It explores continuities and discontinuities between the socio-political and ecological features of a specific portion of Italian territory, a set of multidisciplinary environmental narratives (from c. $600 \mathrm{AD}$ to the present), and local communities. The DBP is meant to be collaborative and provide a digital platform for dialogues between scientists and humanists, a modeling tool for environmental and cultural awareness, and an opportunity for experiential learning and sustainable economic development.

When fully functional, the DBP would supply for both each and all locations mentioned in the Dialogues in which a nonhuman actant plays an important role what geographers call a "deep map" (or "thick map"). A deep map is an attempt to try to comprehend space, place, and time in concert and

5 A quite exhaustive introduction to landscape ecology is Gardner, O’Neill, and Turner, 2001. 
has been recently defined as "a finely detailed, multimedia depiction of a place and the people, animals, and objects that exist within it" (Bodenhamer, Corrigan, \& Harris, 3; 135). A deep map ties together the tangible and the material with the discursive and ideological dimension of a place - matters with meanings - but, unlike conventional maps, it does it privileging "experiential navigation, time-based approaches, participatory mapping, and alternative rhetorics of visualization” (Presner \& Shepard, 207). As Todd Presner writes about the HyperCities project, deep mapping (or, as he calls it, "thick mapping") thus emphasizes "context and meaning-making through a combination of micro and macro analyses that foster a multiplicity of interpretations rather than simply reporting facts or considering maps as somehow given, objective, or complete" (Presner; Shepard; \& Kawano, 19). Consequently, a deep map acknowledges how engaged human agents "build spatially framed identities and aspirations out of imagination and memory" (Bodenhamer, Corrigan, \& Harris, 3) that often require equally engaged nonhuman involvement and participation, as is the case in the Dialogues. The DBP would be a deep map of both the larger portion of central Italy mentioned in Gregory's book and each location, revealing the ties that places have with each other as well as outlining the specific more-than-human temporal and spatial network that has characterized and may still characterize each place. In this sense, as with a deep map, the DBP would be simultaneously a platform, a process, and a product, provoking negotiation between insiders and outsiders, experts and contributors, over what is represented and how $(21 ; 227)$.

A project such as the DBP only now becomes possible thanks to advanced spatial technologies and functions that work through a series of layers corresponding to how traditional GIS operates. As Bodenhamer has pointed out, deep maps and GIS maps ultimately offer a visual interactive space in which the relative transparency of layers allows users to contribute to "a virtual world in which uncertainty, ambiguity, and contingency are ever present but all are capable of being braided into a narrative that reveals the ways in which space and time influences and is influenced by social interaction" (22). They thus both permit us to see a community in which "what is known is not only a function of objects but also of subjects and observers, of what is desired and needs to be known," as well as define place "as sedimented layers of meaning" (22). Having as a point of departure one specific miracle story of the Dialogues and its correspondent location, the DBP proceeds by adding layers of narrative (historical, literary, spatial, etc.) and scientific data with the aim of creating a nearcontinuous ecological stratigraphy from ca. $600 \mathrm{AD}$ to the present. In so doing, it would generate, for each story and location, a collaborative community in which scholars, researchers, and local populations would interact to both reconstruct and negotiate knowledge. My goal is for the DBP to operate as an ecological narrative generation platform, that is to say, a platform that would provide new ecological insights into the correlation, interaction, and structure of ecological events and narratives in space and time. As Delozier, McIntosh, \& Yuan write about their own American Civil War GIS platform, narrative generation is performed by connecting events in space and time based on actors (both biotic and abiotic), action or both "to decipher the spatiotemporal relationships among actors and action in making histories" (181).

For an example of how the DBP is built to perform, I want to take one of my favorite miracle stories of the Dialogues. As Gregory narrates in book 3, chapter 11, Cerbonius was "a man of holy life" and the Bishop of Populonium, modern Populonia, a tiny frazione (hamlet) of the larger town of Piombino in Tuscany today, but in the sixth century AD still an important Roman city, albeit 
increasingly devastated by foreign invasions. As the story goes, once Cerbonius gave shelter to some Christian soldiers and so saved their lives from the Goths. Totila, the Goths' "impious king," learned of the bishop's action and "in great rage and cruelty commanded him to be brought unto a place called Merulis (eight miles from Populonium), where he remained with his whole army, and in the sight of the people to be cast unto wild bears to be devoured." In front of a large crowd (perhaps in a natural amphitheater? In the woods?), Cerbonius was brought forth, where a ferocious bear was waiting: "Out of his den was the beast let loose, who in great fury and haste set upon the Bishop: but suddenly, forgetting all cruelty, with bowed neck and humbled head, he began to lick [Cerbonius'] feet: to give them all to understand that men carried towards the man of God the hearts of beasts, and the beasts as it were the heart of a man." As Ziolkowski has pointed out, this story can be read as just one example of the several biographical saints' narratives in which wild bears play a positive ex machina role, somehow rescuing, submitting to, or entering the service of holy personages (Ziolkowski 2017, 30). Although this religious and theological aspect is certainly crucial for a correct interpretation of the story and its historical repercussions, for the DBP it would be only a point of departure. From the perspective of the environmental humanities, what is interesting is that bears are no longer part of the Tuscan landscape, their presence in central Italy being almost completely limited to the Abruzzo National Park, where they are severely endangered. The story of Cerbonius as narrated in the Dialogues instead implicitly assumes these nonhuman animals still lived in that territory and thus offers us an opportunity to explore the symbolic and material interactions that the local human community and the bears have had throughout the centuries. What in fact happened to the bears? When did they disappear? Why? And how has the story of Cerbonius influenced the local community? Do we still have visible signs of this story in the landscape? And what other further narratives might these possible signs have created and still create? Can we use this story as the base for a new understanding of the Tuscan landscape that would potentially enhance both ecological care and cultural prosperity?

To answer these questions (and others that might arise from further in loco investigations), an interdisciplinary team of scholars, students, and local experts must be assembled, a team capable of tackling the multifaceted complexity implicit in the miracle story. For example, in the case of Cerbonius, a student majoring in Classics (Latin literature), a zoologist, and a historian of Europe might collectively analyze the presence and significance of bears as narrated in the Dialogues. In this hypothetical scenario, their interaction provides each of them with specific advantages: the student's research on bears in Latin literature can be enriched by the ethological and historical expertise of the two senior scholars; the zoologist's research on bears in Italy profits from the linguistic and historical depth presented by the student and the historian, respectively; the historian's work benefits from both the etymological and literary perspective provided by the student and the zoological precision offered by his colleague in Zoology. Lastly, the interdisciplinary research output generated by the academic cooperation interacts with popular and often orally-transmitted knowledge possessed by local communities about human-bear relationships in their own territory. This interaction would provide data otherwise unavailable to the scholars as well as scientific, historical, and environmental awareness to local communities interested also in investing responsibly in that specific landscape. 


\section{Current State of the Project}

Thanks to a CompX Faculty Grant awarded by the Neukom Institute for Computational Science at Dartmouth College, I have been able to work with a few colleagues of the Dartmouth Research Computing team and a student of mine to develop the digital frame that will eventually host the DBP.6

We first selected the stories in the Dialogues in which nonhuman, environmental features played a crucial landscape function: as I mentioned in the previous section, circa seventy of them were selected and the locations in which the miracle or wonder occurred were annotated. Some of the locations were not mentioned by Gregory with geographical precision, but we still managed to pinpoint with reasonable certainty the majority of them thanks to external sources, like local history or religious scholarship. Interestingly, not all of them are still active centers of social and/or spiritual life. Instead, several of the locations mentioned in the Dialogues have been abandoned and have therefore lost the once-established connection between the local environment and the human community. However, even when this connection is still present - namely, a human community dwells upon the same territory mentioned by Gregory - the original link as narrated in the book is often overlooked, if even acknowledged at all: a few ruins are usually the only signs to remind us of the original organization of that specific landscape.

Once all the locations were identified, we then marked the stories according to the main characteristic of their nonhuman actants: if in the story there was a nonhuman animal, it would be marked as "zoological"; a plant of any kind would mean "botanical" feature; a body of water, "hydrological;" a stone, boulder, or any type of rock, "geological." We assigned different icons to these features: a bear, a Mediterranean stone pine, a waterfall, and a mountain, respectively. Those icons were selected for practical reasons, but they might be changed in the future, if necessary. Sometimes the same story may have different markers, such as in the case of the only story in which the four of them appear. It is the story of Marcius, a reverent man "who lived a solitary life in the mountain of Marsico" (book 3, chapter 16), the modern Monte Massico, a mountain situated in the Italian Province of Caserta. As Gregory narrates, Marcius lived a solitary life in "a narrow and straight cave" (geological marker) where one day he managed to cause water to be "sprung (...) out of the hollow rock" (hydrological). However, the very same day a "serpent alone would come into the cave where he lived also alone, and when he was at his prayers, it would cast itself before him, and when he took his rest, it would lie down by his side" (zoological). The holy man was not at all dismayed at this and often talked to the snake, until, after three years of this cohabitation, the serpent "made a great hissing, and tumbling himself down by the side of the mountain, he consumed all the bushes and shrubs with fire" (botanical).

The next step was the creation of a digital map of Central Italy. We opted for a multilayered outline in which users could select four different maps by clicking the layer control icon. The first map is the Open Street Map (OSM) as part of the collaborative project that goes under the same name: it contains

6 I want to thank specifically the Director of the Neukom Institute, Dan Rockmore; the colleagues in Research Computing with whom I collaborated, especially Steven Gaughan, Douglas Hill, and John Wallace; and the Dartmouth student who worked on the initial database with me, Wes Kendrick. I avail myself of this opportunity to thank also Hailey LaVoy and Martin Bloomer who generously brought Gregory's Dialogues to my attention and with whom I had several conversations about this work and its importance. Finally, my gratitude goes to the anonymous reviewers of this article. 
fine detail on roads and footpaths and it would be helpful if users contemplate visiting a site mentioned in the Dialogues (fig.1).

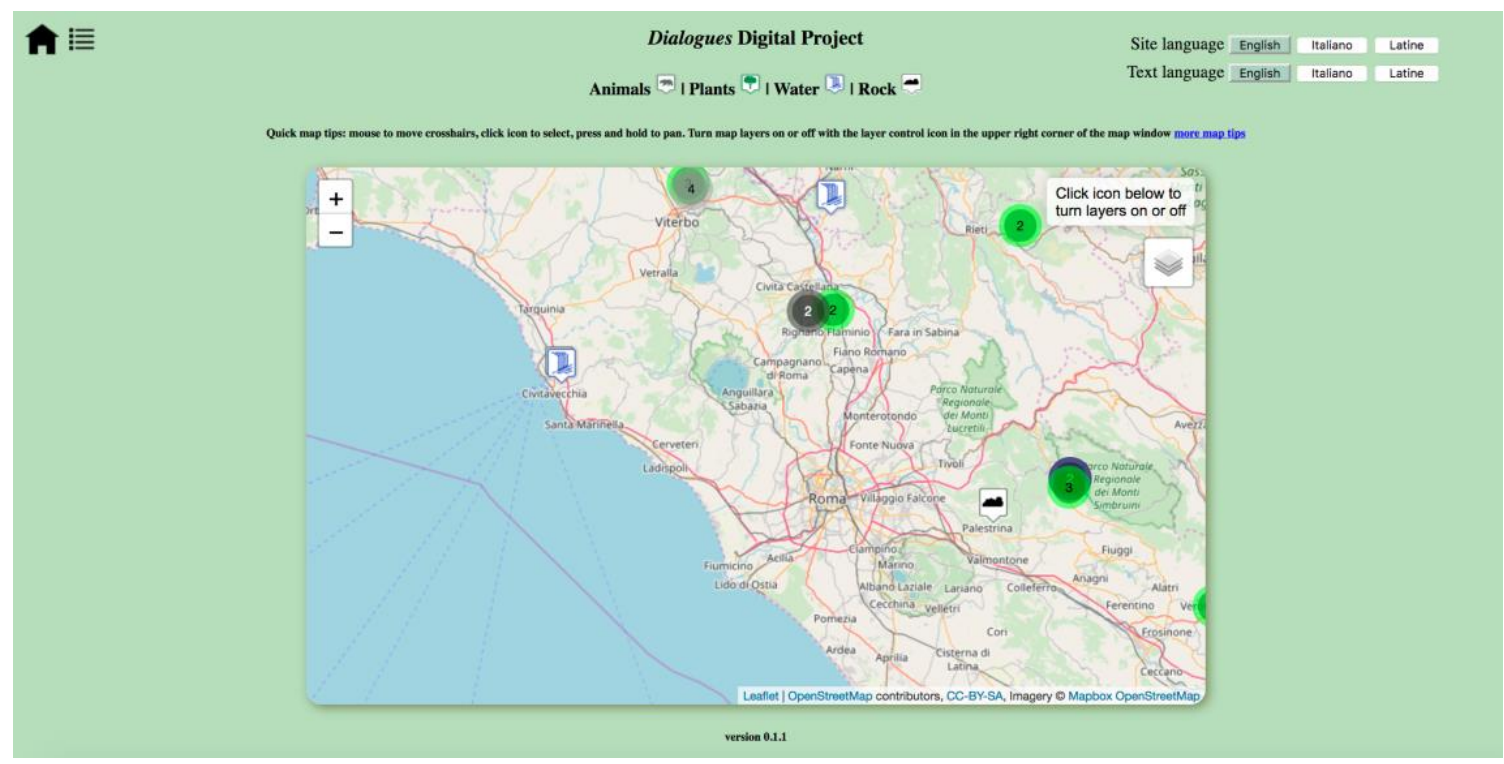

Figure 1. Open Street Map.

There are then a "Satellite map" and a "Street/Terrain map" which may both help visualize the landscape (fig. 2 \& 3).

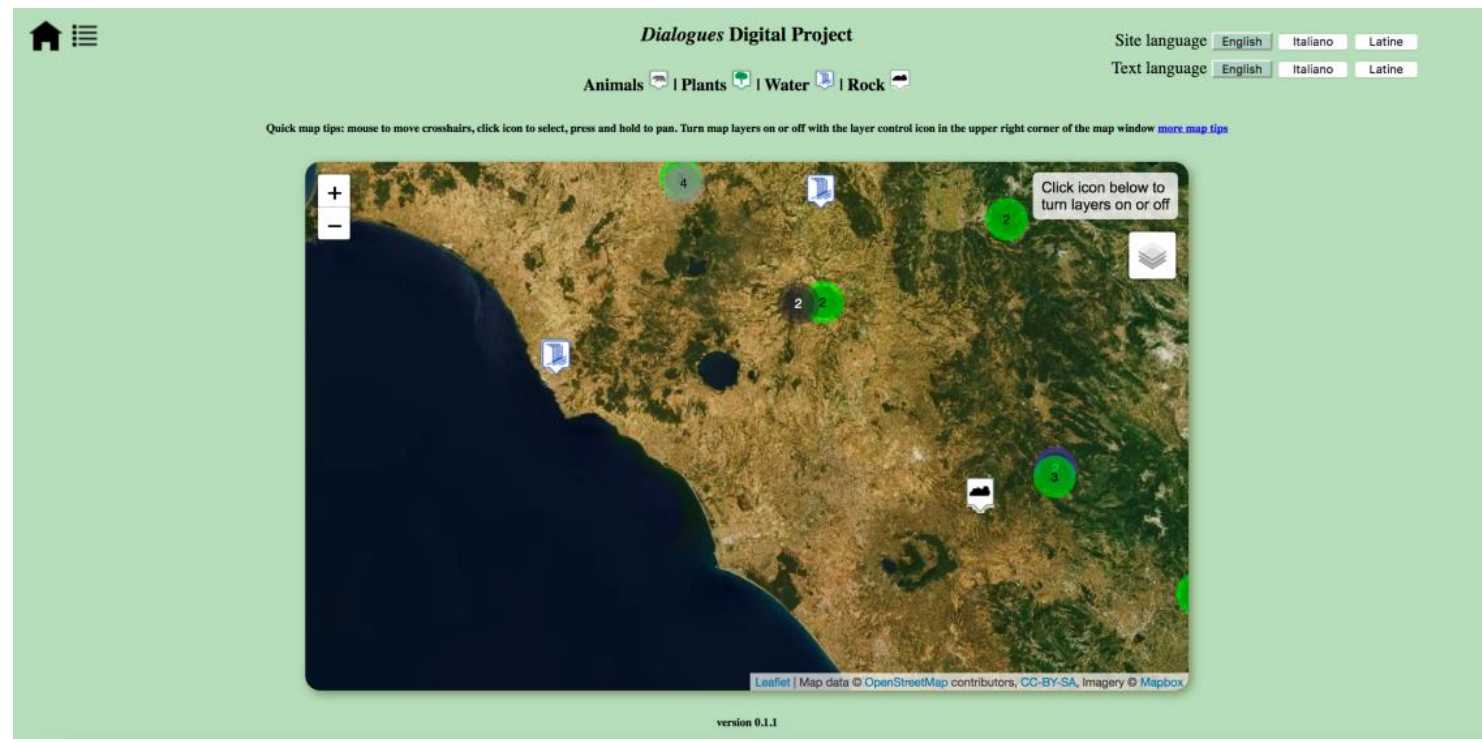

Figure 2. Satellite map. 


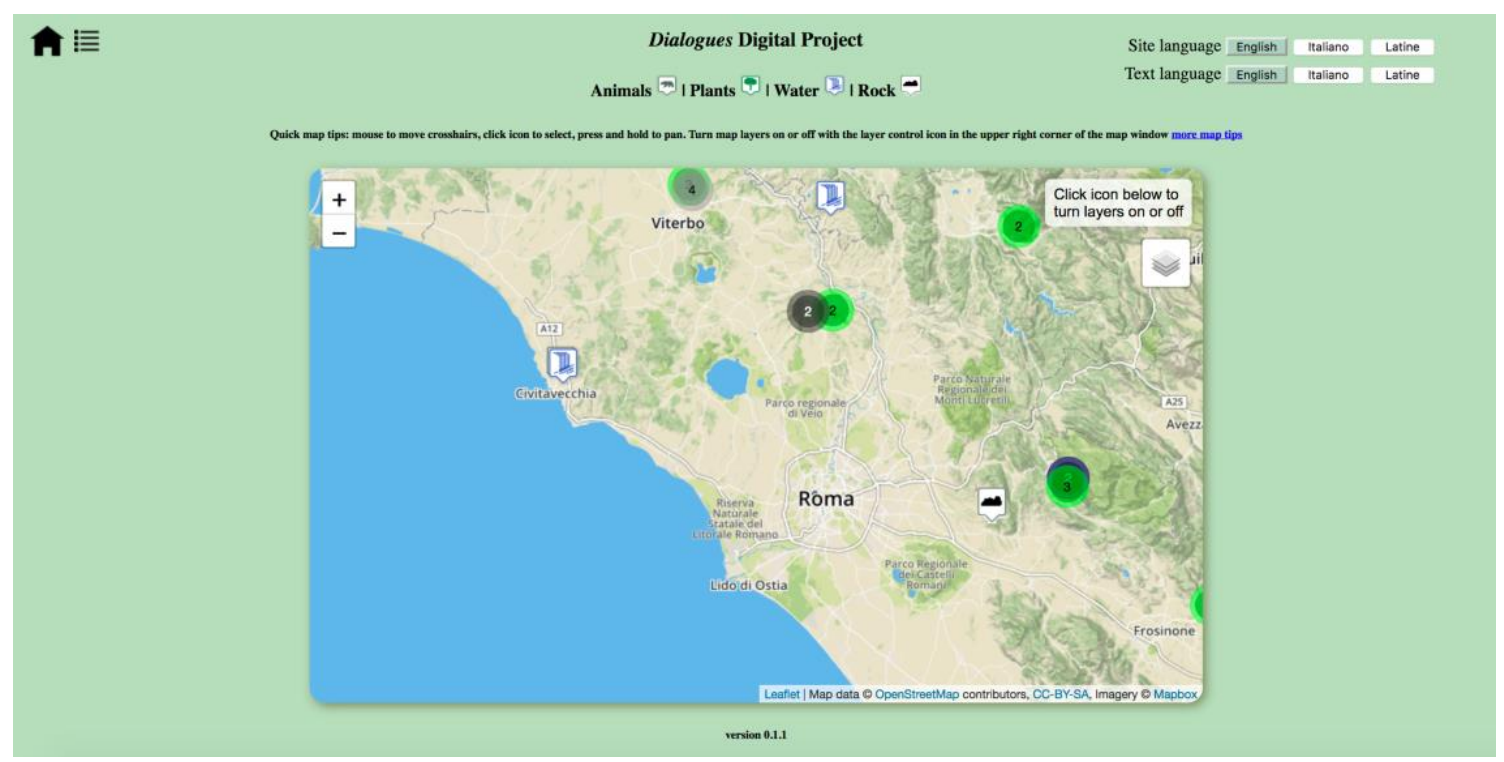

Figure 3. Street/terrain map.

Finally, we decided to have a "Roman map" that shows features from the time of Imperial Rome, somewhat before Gregory's day (fig. 4).

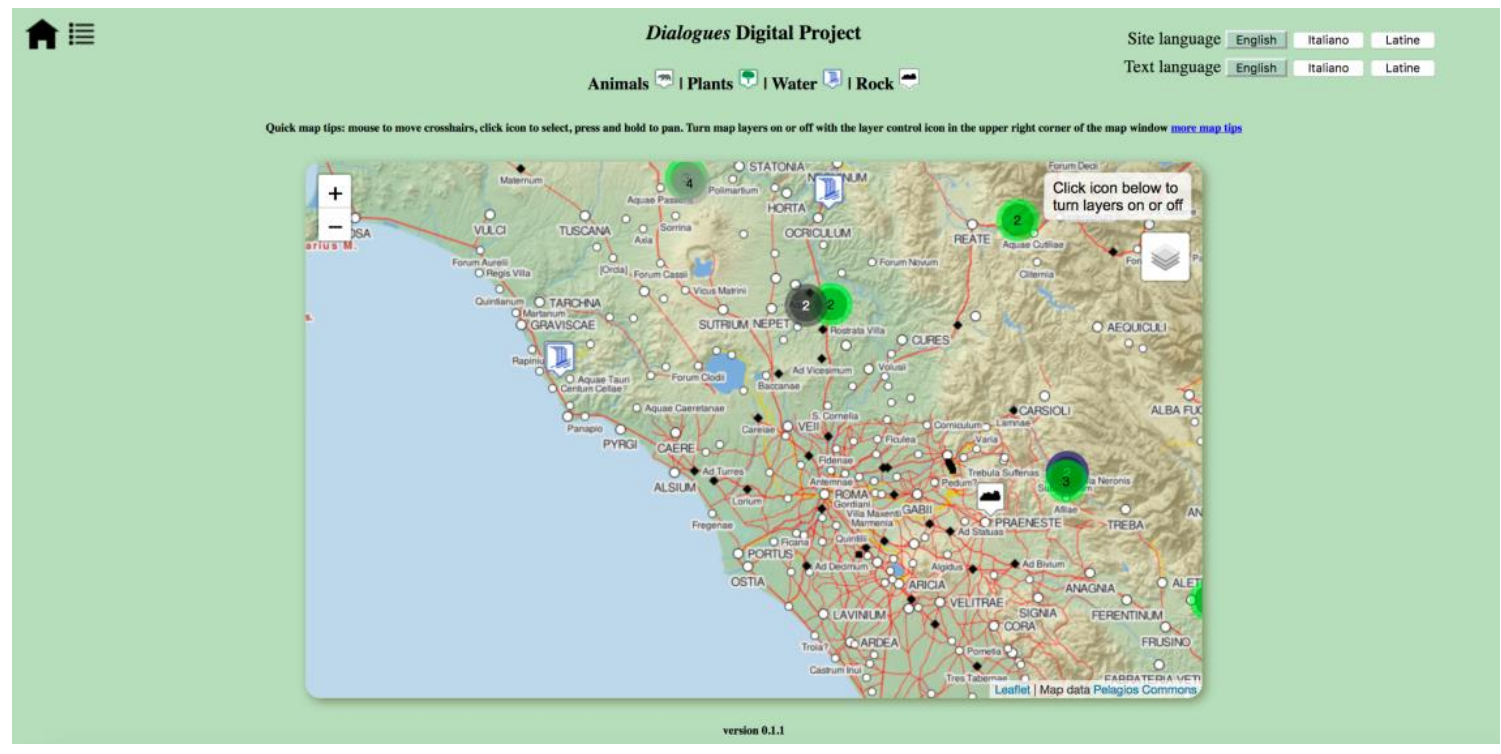

Figure 4. Roman map.

It is less detailed than present day maps, so one may not be able to select Roman if they zoom in too far, but it offers the toponymy of the time, the same used by Gregory in the original Latin. Given the importance of people's movement and travel in the Dialogues, the Roman map also contains the major Roman roads radiating from the Capital of the empire to the various provinces. We are also 
contemplating introducing further maps featuring, for example, the different ecosystems or land uses, but they are not currently part of the platform.

We then inserted the markers for each category into the multilayered map. Users can view markers from more than one category at once, but markers from identical locations may obscure each other, so we decided to allow users to switch off one or more category if they are unable to click on the marker they want. To facilitate the navigation of the platform we also added clusters. So, if two or more markers from the same category are close enough to overlap, they are replaced by a colored circle, with a number showing how many markers it represents. When a user clicks on the circle, the map zooms enough to separate at least one of the markers. If all the markers in the circle are all in the same location, they are redrawn on rays around the central locations, so that they are far apart enough to be clicked separately (fig. 5).

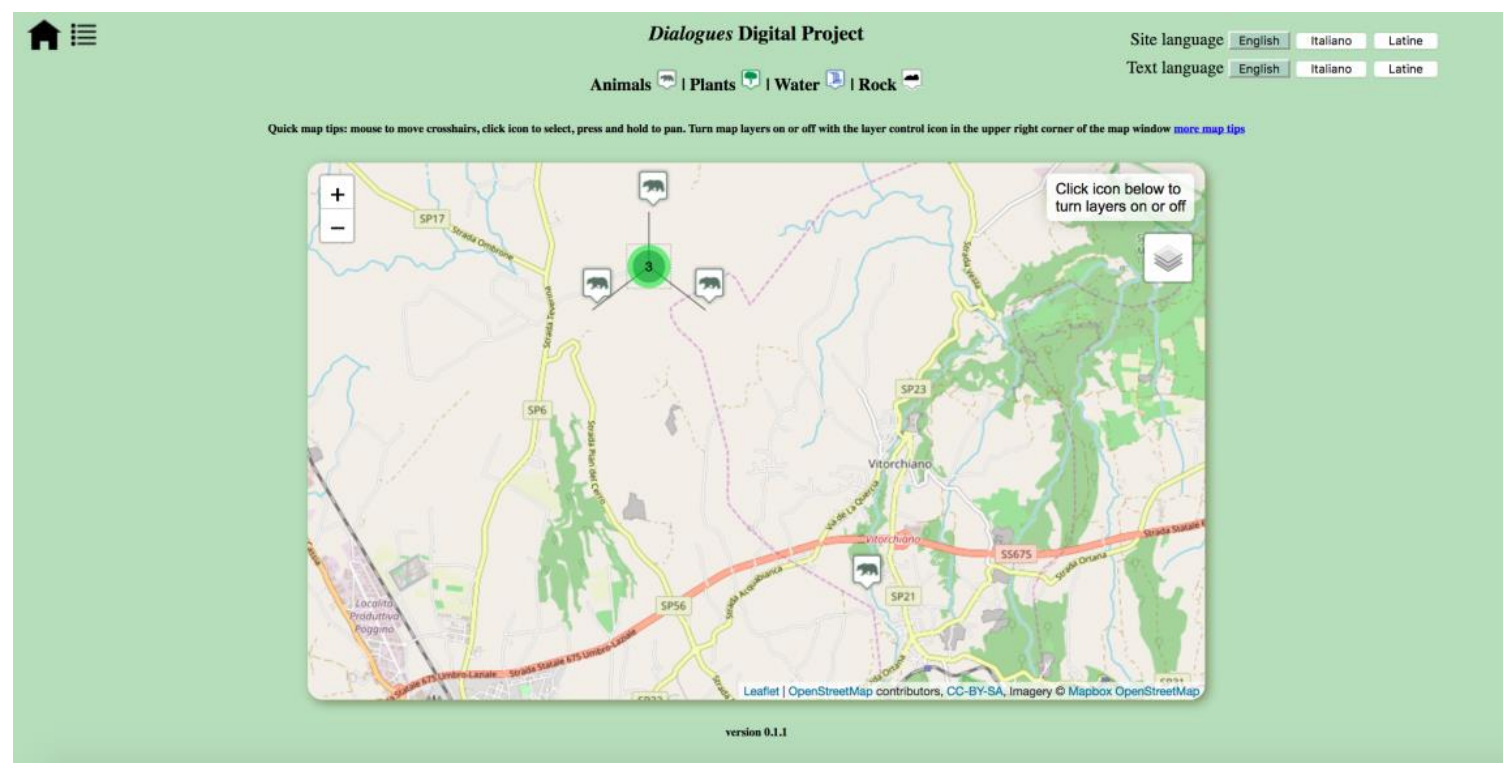

Figure 5. Rays around a central location.

Lastly, when users click on a map marker, the Text Information Panel appears, containing the relevant Dialogues text (fig. 6). 


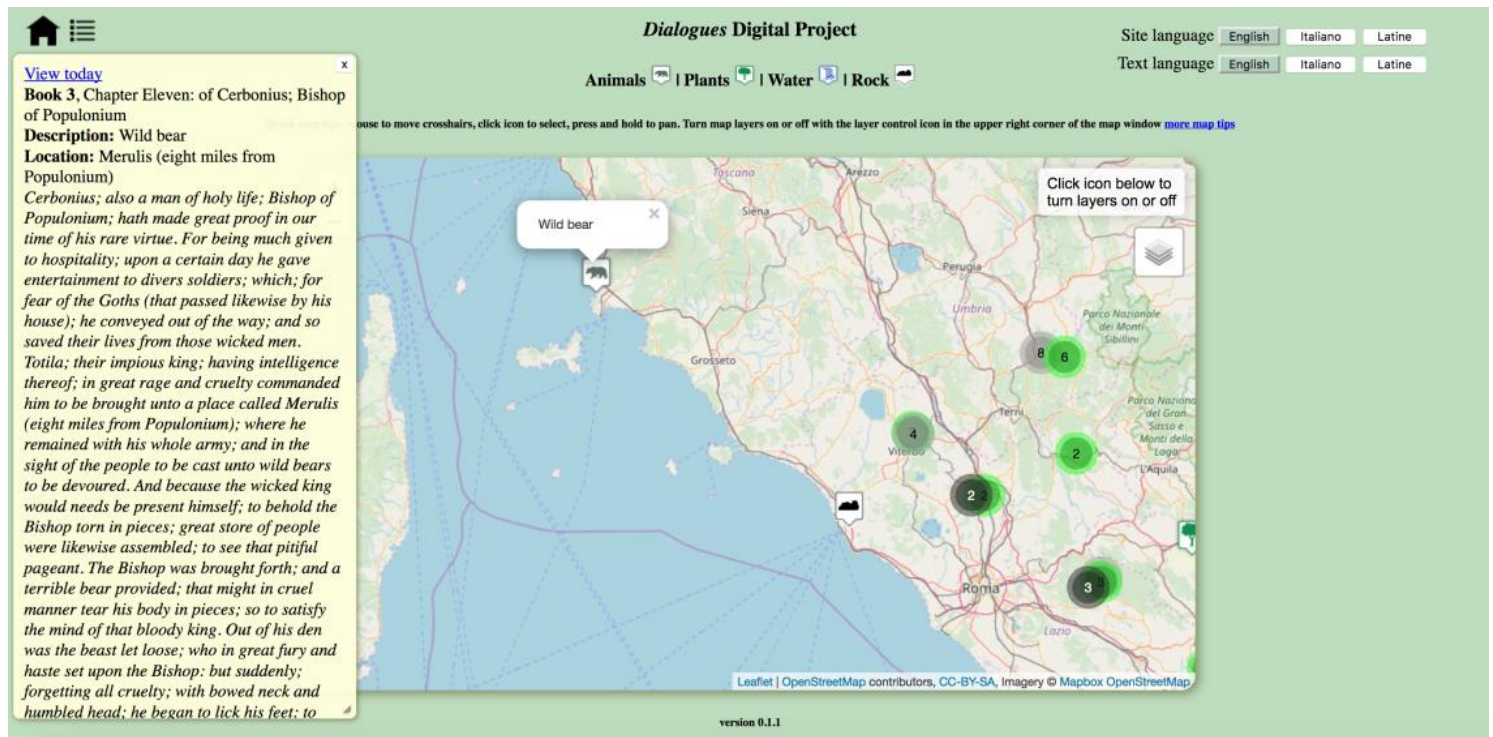

Figure 6. Text Information Panel.

Currently, only the English translation is available, but we created in advance space for the original Latin as well as for the Italian translation. A user can drag and resize this panel if it is inconveniently placed. In the top of this panel is a View today link. Clicking this will bring up a Google Maps Street view for the location. Of course, the actual location for an event related in a miracle story written 1500 years ago must be quite approximate, so users can enjoy the view if they would like to see the contemporary landscape, but they should not expect to see most of the environmental features described in the Dialogues. For this feature, we are currently using Google Maps, which unfortunately has no imagery for some of the most remote locations.

The next step for the DBP would be to provide all these marked locations and their respective miracle stories with team of scholars capable of producing both inter- and extra-textual hyper-linked narratives. For example, to return to the story mentioned earlier, a team might focus on Cerbonius and the bear and produce: an interpretation of the meaning of bears in Gregory's work and in this story in particular; a zoological account of possible bear species present in the Italian peninsula; a historical (diachronic) reconstruction of the presence of bears in that specific territory; a list of other literary or visual accounts in which bears appear and their significance; a set of zoo-anthropological explorations about the relationship between bears and human beings in general and in that territory more specifically; a set of recorded contributions by local communities about the presence (or absence) of bears in their environment; a study on the importance of bears for the general ecology of that specific territory, etc. Needless to say, these are only some of the directions each team can take, and the outcome will be determined by the specific interests of each team and open to further development. At the same, it will be crucial to engage not only with local communities and their specific knowledge of the territory, but also with the Italian government (and potentially the EU). As I mentioned above, one of the aspirational goals of the DBP is to develop forms of environmentally and culturally responsible tourism in relation to the multi-faceted and interdisciplinary narratives created by the project, and therefore institutional support becomes paramount. A further development 
of the project, at this point even too ambitious, is to create an application through which users can read the Dialogues on their favorite electronic devices, follow the text to explore simultaneously the narratives created by the project and the locations, and eventually have direct access to those locals who would be willing to engage with this kind of environmentally- and culturally-conscious tourism.

\section{Conclusion}

In his Vita Gregorii Magni, Paul the Deacon (c. 720-790) describes a moment in Gregory's life when Gregory was dictating his homilies on Ezechiel to his secretary through a veil drawn between the two of them. According to the legend, as the pope remained silent for long periods at a time, the servant made a hole in the curtain and, looking through, "beheld a dove seated upon Gregory's head with its beak between his lips. When the dove withdrew its beak, the holy pontiff spoke and the secretary took down his words; but when he became silent the servant again applied his eye to the hole and saw the dove had replaced its beak between his lips" (xxviii). Although the dove was meant to symbolize the Holy Spirit and therefore the divine inspiration moving Gregory, when it comes to the Dialogues the story also suggests a fascinating circularity: the source for Gregory's inspired stories about the nonhuman world and its crucial interaction with the human one comes from a nonhuman creature whispering (singing?) words into his mouth, which Gregory then delivered to his human listener.

In this article, I outlined how this potential circularity and reciprocity between the nonhuman environment and the human culture and society as described in some of Gregory's miracle stories in the Dialogues can promote new ecological narratives, knowledge, and awareness. I have also briefly sketched out premises, major features, and potentials of my digital project based on Gregory's work, summarizing what has been done so far and what ought to be realized in the future. As I stated in the introduction, my hope is to create a community of scholars, students, and locals interested in participating in the project and advance its environmental agenda. In fact, I truly believe that deep mapping the sacred human-nonhuman interactions depicted in the Dialogues would eventually create a new (culturally) sacred landscape and help protect these often overlooked and abandoned environments from that "filling" or riempimento that Turri saw as an increasing dangerous possibly for Italy.

As Frascaroli has pointed out in his preliminary study of the potential of sacred natural sites for biodiversity management in central Italy, the link between sacredness and natural areas has rightly been deemed to offer crucial opportunities (587). The aim of the DBP is to leverage computer technology to provide a digital platform through which scholarly collaboration would help the sacred territories described in Gregory's Dialogues re-acquire their eco-historical significance and therefore reconstruct a symbolic and material link between spiritual beliefs, human communities, and the environment. In a country like Italy, whose patron saint is Frances of Assisi - who is also patron saint of animals and the natural environment - this should be considered a priority.

However, different from what Frascaroli aim, the DBP is not mainly meant to shed light on the sacred as "the possible ultimate source of a conservationist ethos" (588) and therefore to separate these spaces from the environmental and socio-economic struggles of local populations. Instead, the radical ambition of the project is to provide those local communities with a tool meant to reestablish a meaningful and productive connection with their own environment and thus draw ecological as well 
as economic progress. As Cesaretti, Iovino, and Past write, "the lack of a bond between cultural identity, social awareness, and environmental protection is indeed at the core of the ecological crisis" (8). I agree with the editors of Italy and the Environmental Humanities that Italy needs now more than ever to concoct (environmental) progress with (economic and cultural) development, thus reinforcing "the mutual formative bond of humans and place, something which could constitute the premise for a healthy life, both in physical and political term" (8). The DBP is thus meant to be a tool for socioenvironmental justice and development rather than an element of conservationist ideology. Ultimately, I hope this project will encourage communities to re-approach their natural settings in ecological terms, by engaging in dialogue with other experiences through history and literature. Perhaps then we can slow the increasing abandonment of these landscapes to either real estate speculation or our (privileged) fantasies of pure, untouched wilderness.

\section{Works Cited}

Bodenhamer, David. "Narrating Space and Place." Deep Maps and Spatial Narratives, edited by D. Bodenhamer, J. Corrigan, and T. Harris. Bloomington, IN: Indiana University Press, 2015, pp. 727. Print

Bodenhamer, David; John Corrigan; and Trevor Harris (eds.). Deep Maps and Spatial Narratives. Bloomington, IN: Indiana University Press, 2015. Print.

Boesch Gajano, Sofia. Gregorio Magno. Alle origini del Medioevo. Roma: Viella, 2004. Print.

Boesch Gajano, Sofia. "Loca sanctorum: la geografia sacra tra tardo antico e altomedioevo." Martiri, santi, patroni - per una archeologia della devozione: atti X Congresso Nazionale di Archeologia Cristiana ; Università della Calabria, Aula Magna, 15 - 18 settembre 2010, edited by A. Coscarella and P. De Santis. Reggio Calabria: Università della Calabria, 2012, pp. 3-16. Print.

Caseau, Béatrice. "Sacred Landscapes." Late Antiquity: A Guide to the Postclassical World, edited by G. W. Bowersock, P. Brown, and O. Grabar. Cambridge, MA: Harvard University Press, 1999, pp. 21-59. Print.

Cesaretti, Enrico; Serenella Iovino; and Elena Past (eds.). Italy and the Environmental Humanities. Landscapes, Natures, Ecologies. Charlottesville, VA: University of Virginia Press, 2018. Print.

Clark, Francis. "The Authenticity of the Gregorian Dialogues: A Reopening of the Question?.” Grégoire le Grand, Colloques internationaux du Centre National de la Recherche Scientifique, edited by J. Fontaine, R. Gillet, and S. Pellistrandi, Paris, 1986, pp. 429-443. Print.

Clark, Francis. The "Gregorian" Dialogues and the Origins of Benedictine Monasticism. Leiden/Boston: Brill, 2003. Print.

Cremascoli, Giuseppe. “I 'viri Dei’ dell’Umbria nei 'Dialogi' di Gregorio Magno.” Umbria cristiana. Dalla diffusione del culto al culto dei santi (secc. IV -X). Atti del XV Congresso Internazionale di studio sull'alto medioevo, Spoleto 23-28 ottobre 2000, Spoleto, 2001, pp. 257-270. Print.

DeLozier, Grant; John McIntosh; and May Yuan. "GIS as a Narrative Generation Platform.” Deep Maps and Spatial Narratives, edited by D. Bodenhamer, J.Corrigan, and T. Harris. Bloomington, IN: Indiana University Press, 2015, pp.179-202. Print. 
Frascaroli, Fabrizio. "Catholicism and Conservation: The Potential of Sacred Natural Sites for Biodiversity Management in Central Italy.” Human Ecology, vol. 41, no. 4, 2013, pp. 587-601. Print.

Gardner, Robert; Robert O'Neill; and Monica Turner. Landscape Ecology in Theory and Practice. New York: Springer, 2001. Print.

Grégoire, Réginald. 'L'osservazione di alcune situazioni naturali ambientali e lavorative nei 'Dialoghi' di Gregorio Magno.” Per longa maris intervalla: Gregorio Magno e l'Occidente mediterraneo fra tardoantico a altomedioevo, atti del convegno internazionale di studi, Cagliari 17 - 18 dicembre 2004, edited by L. Casula, G. Mele, and A. Piras. Cagliari: Studi e Ricerche di Cultura Religiosa (NS4), 2006, pp. 75-90. Print.

Gregory the Great. The Letters of Gregory the Great. Toronto: Pontifical Institute of Mediaeval Studies, 2004. Print.

Gregory the Great. Dialogues. Middletown, DE: ExFontibus, 2016. Print.

Harris, Trevor. "From PGIS to Participatory Deep Mapping and Spatial Storytelling: An Evolving Trajectory in Community Knowledge Representation in GIS." The Cartographic Journal, vol. 53, no. 4, 2016, pp. 318-325. Print.

Iovino, Serenella, and Serpil Opperman (eds). Material Ecocriticism. Bloogminton, IN: Indiana University Press, 2014. Print.

Laghezza, Angela. "Fonti e testimoni nei Dialoghi di Gregorio Magno." Vetera Christianorum, vo. 46, 2009, pp. 261-291. Print.

Laghezza, Angela. "L’Italia meridionale nei Dialoghi di Gregorio Magno: le ragioni di una assenza." Auctores Nostri, vol. 11, 2012, pp. 247-259. Print.

Lynch, Tom; Cheryll Glotfelty; and Karla Armbruster. The Bioregional Imagination. Athens: University of Georgia Press, 2012. Print.

McCready, William. Signs of Sanctity. Miracles in the Thought of Gregory the Great. Toronto: Pontifical Institute of Mediaeval Studies, 1989. Print.

Petersen, Joan. The Dialogues of Gregory the Great in their Late Antique Cultural Background. Toronto: Pontifical Institute of Mediaeval Studies, 1984. Print.

Presner, Todd, and David Shepard. "Mapping the Geospatial Turn." A New Companion to Digital Humanities, edited by S. Schreibman, Ray Siemens, and John Unsworth. Hoboken, NJ: Wiley, 2015, pp. 199-212. Print.

Presner, Todd; David Sphepard; and Yoh Kawano. HyperCities. Thick Mapping in the Digital Humanities. Cambridge, MA: Harvard University Press, 2014. Print.

Spera, Lucrezia. "The Christianization of Space along the via Appia: Changing Landscape in the Suburbs of Rome.” American Journal of Archaeology, vol. 107, no. 1, 2003, pp. 23-43. Print.

Springett, Selina. "Going Deeper or Flatter: Connecting Deep Mapping, Flat Ontologies and the Democratizing of Knowledge.” Humanities, vol. 4, no. 4, 2015, pp. 623-636. Print.

Straw, Carole. Gregory the Great: Perfection in Imperfection. Berkeley: University of California Press, 1991. Print. 
Tuan, Yi-Fu. Space and Place. The Perspective of Experience. Minneapolis: University of Minnesota Press, 1977 [2001]. Print.

Tuan, Yi-Fu. "Sacred Space; Exploration of an Idea." Dimension of Human Geography, edited by K. W. Butzer. Chicago: University of Chicago, Department of Geography Research Paper No. 1876, 1978, pp. 84-99. Print.

Turri. Eugenio. Il paesaggio e il silenzio. Padova: Marsilio, 2010. Print.

Ziolkowski, Eric. "From Ursus diabolus to Ursus ex machina: The Ambivalent Legacy of Biblical Bears in Literature and Art." Fallen Animals: Art, Religion, Literature, edited by Z. HadromiAllouche. Lanham, MD: Lexington Books, 2017, pp. 23-46. Print. 